\title{
Broca's area
}

Andrew Silverman, ScB

Neurology ${ }^{\circledR}$ 2020;95:269. doi:10.1212/WNL.0000000000009994
Correspondence

Andrew Silverman

Andrew.Silverman@yale.edu

Bienvenue, one and all, to my neighborhood-my area, as it were

Or perchance best understood

As my district, zone, locality, or quarter

Though I do apologize, there is no porter

Mais oui! A porter, garçon, a carrier-

Someone to assist with your paraphernalia

But fear not, for I am your host, Monsieur Broca! and if I may say,

Enchanté, pleased to make your acquaintance, here in my oasis

I shall embody, as always, a manner most gregarious and gracious,

But please forgive my unrestrained proclivity - that is, my speech, my parlance-

For I am eternally and reflexively loquacious

And what brings you here to my operculate park, the left frontal lobe,

The premier learned lexicon within the lobe of lobes?

Ah, the pressure is too high, you say?

The cerebrum has a growth, and you intend to operate?

Indeed, real estate, as it were, is extraordinarily tight

Contained within a cranium of immutable calcite-

Scream and shout to your heart's content,

The indifference of the skull,

That boney crab, that concavely unwavering tent,

Will merely reflect the sound

Back to your own incisive ears

It is not, take my word, worth a drop of your tears

A structure rises, the skull budges not,

And thus, a structure must fall

The first law of thermodynamics, in a way, if you will, as it were-

Now, my scalpel sporting friend, doth time waste me,

But let it not waste you - carry on, carry on

Bearing in mind, yours not mine, that the borders you find

May cast a sesquipedalian disposition into dull but defiant light

Defiant, mais oui, aphasia be damned!

I will hide my words in unexpected places

Underneath concealed plastic cases,

The very same plastic potentiation and cortical reorganization

That will k-k-keep ma-ma-ma-my sp-spa-spi-spirit a-a-a-a

Alive! 


\title{
Neurology
}

\author{
Broca's area \\ Andrew Silverman \\ Neurology 2020;95;269 Published Online before print June 15, 2020 \\ DOI 10.1212/WNL.0000000000009994
}

This information is current as of June 15, 2020

$\begin{array}{ll}\begin{array}{l}\text { Updated Information \& } \\ \text { Services }\end{array} & \begin{array}{l}\text { including high resolution figures, can be found at: } \\ \text { http://n.neurology.org/content/95/6/269.full }\end{array} \\ \text { Subspecialty Collections } & \begin{array}{l}\text { This article, along with others on similar topics, appears in the } \\ \text { following collection(s): } \\ \text { Aphasia } \\ \text { http://n.neurology.org/cgi/collection/aphasia } \\ \text { Plasticity } \\ \text { http://n.neurology.org/cgi/collection/plasticity }\end{array} \\ & \begin{array}{l}\text { Information about reproducing this article in parts (figures,tables) or in } \\ \text { its entirety can be found online at: } \\ \text { http://www.neurology.org/about/about_the_journal\#permissions } \\ \text { Permissions \& Licensing }\end{array} \\ \text { Information about ordering reprints can be found online: } \\ \text { http://n.neurology.org/subscribers/advertise }\end{array}$

Neurology ${ }^{\circledR}$ is the official journal of the American Academy of Neurology. Published continuously since 1951, it is now a weekly with 48 issues per year. Copyright () 2020 American Academy of Neurology. All rights reserved. Print ISSN: 0028-3878. Online ISSN: 1526-632X.

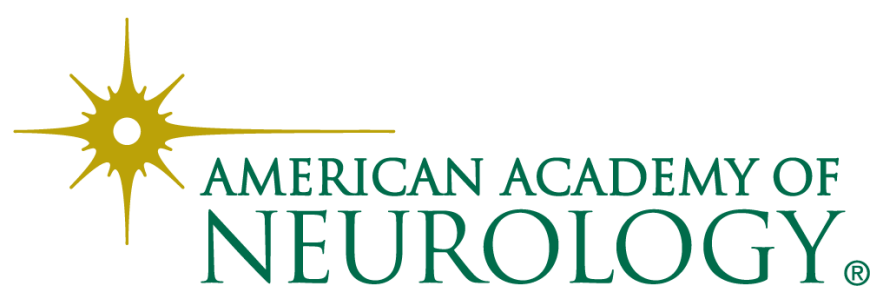

